\title{
Stimulation of exocrine pancreatic secretion by met-enkephalin
}

\author{
L GULLO, PATRIZIA PRIORI, F BALDONI, AND G MATTIOLI \\ From the Unit for the Study of Pancreatic Disease, Institute of Medicine and Gastroenterology, University of \\ Bologna, St. Orsola Hospital, Bologna, and Division of Surgery, Maggiore Hospital, Bologna, Italy
}

SUMmaRY The effect of met-enkephalin on pure exocrine pancreatic secretion was studied in five subjects with external transduodenal drainage of the main pancreatic duct carried out after biliary tract surgery. Intravenous infusion of a low dose of met-enkephalin $(0 \cdot 15 \mu \mathrm{g} / \mathrm{kg} / \mathrm{h})$ during submaximal pancreatic stimulation with secretin $(25 \mathrm{ng} / \mathrm{kg} / \mathrm{h})$ and cerulein $(10 \mathrm{ng} / \mathrm{kg} / \mathrm{h})$ significantly increased pancreatic outputs. Bicarbonate secretion increased $50 \%$ above control values, a more marked effect than the increase in enzyme secretion (maximal rise averaged $22 \%$ ). The effect of the peptide was rapid, persisted for the duration of met-enkephalin infusion and then tended gradually to diminish.

Available information concerning the effects of opioid drugs and peptides on human exocrine pancreatic secretion is limited. In a recent study, we showed that the administration of a small dose of morphine during pancreatic stimulation with secretin and cholecystokinin caused a marked increase in both pancreatic juice flow and bicarbonate secretion, and a slight decrease in enzyme secretion. The addition of naloxone to morphine infusion prevented in part the effects of the opioid drug, suggesting that specific opiate receptors might be involved. The present study was designed to examine the effect of the naturally occurring opioid peptide, met-enkephalin, on human exocrine pancreatic secretion. As in the previous study with morphine, the effect of met-enkephalin was assessed directly by analysing pure pancreatic juice collected by external transduodenal drainage of the main pancreatic duct.

\section{Methods}

SUBJECTS

Five subjects, four men and one woman (mean age 59 years, range $46-70$ ), free from pancreatic disease, were studied. Written informed consent was obtained from all subjects. The method for collecting pure pancreatic juice has been described in

Address for correspondence: Lucio Gullo. M.D.. Istituto di (linica Medica Gastroenterologia. Ospedale S. Orsola, f(0138 Bologna. Italy.

Received for publication 22 April. 1986 previous publications. ${ }^{12}$ The patients had a transduodenal drainage of the main pancreatic duct carried out after papillotomy and sphincteroplasty for common bile duct stones. The appearance of the pancreas at operation was normal in all patients. The drainage of the main pancreatic duct was not carried out specifically for the purpose of this study, but as a part of the therapeutic programme to prevent postoperative acute pancreatitis. ${ }^{3}$ The polyethylene tubes used to drain pancreatic juice were inserted into Wirsung's canal to a depth of about $3 \mathrm{~cm}$, and were tied to the duodenal wall by a stitch of catgut. They were provided with some additional holes in the intraductal portion and their diameter accurately selected in each patient according to the calibre of the main pancreatic duct. Studies were started six or seven days after the operation and were carried out in the morning after an overnight fast. The effect of met-enkephalin on pancreatic secretion was evaluated during a constant intravenous infusion of secretin, $25 \mathrm{ng} / \mathrm{kg} / \mathrm{h}$, plus cerulein, $10 \mathrm{ng} / \mathrm{kg} / \mathrm{h}$. These doses of secretin and cerulein have been shown to mimic the normal postprandial secretion. ${ }^{4}$ Secretin was obtained from Kabi Diagnostica, Sweden, and cerulein from Farmitalia, Milan, Italy. Continuous aspiration of gastric contents was designed to prevent entry of acid into the duodenum. In addition, $200 \mathrm{mg}$ cimetidine were administered before each study. Pancreatic juice was collected into ice chilled graduated tubes at 10 minute intervals. After six 10 minute periods from the beginning of secretin- 
cerulein infusion - that is, when the rate of flow was stable, met-enkephalin (Peninsula Laboratories, Belmont, California), dissolved in physiological saline containing $0 \cdot 3 \%$ human serum albumin, was infused for 40 minutes at a dose of $0 \cdot 15 \mu \mathrm{g} / \mathrm{kg} / \mathrm{h}$. The secretin-cerulein infusion was then continued for a further 30 minutes. The study was repeated on a separate day using the same procedure, except that physiological saline was given instead of metenkephalin. The dose of met-enkephalin used in this study was based upon studies of Skov Olsen $e t$ al $l^{5}$ of the effect of met-enkephalin on human gastric secretion. These investigators found that metenkephalin at the dose of $0 \cdot 1 \mu \mathrm{g} / \mathrm{kg} / \mathrm{h}$ stimulated gastric acid secretion, whereas at $1 \mu \mathrm{g} / \mathrm{kg} / \mathrm{h}$ it had no effect.

Each 10 minute sample of pancreatic juice was analysed for volume, bicarbonate, and total protein as a measure of enzyme secretion. Bicarbonate concentration was determined by the method of Van Slyke and Neil, ${ }^{6}$ and protein concentration by the absorbance at $280 \mathrm{~nm}^{7}$

Results are presented as means \pm SEM. Statistical significance was assessed by Student's $t$ test for paired data.

\section{Results}

Figure 1 shows the effect of met-enkephalin infusion on pancreatic juice flow and bicarbonate concentration and output. The administration of the peptide caused in all subjects a significant increase in volume and bicarbonate secretion. The effect appeared immediately, and persisted for the duration of met-enkephalin infusion. At the end of the study that is, 30 minutes after stopping met-enkephalin administration, volume and bicarbonate output were still higher than the control values, but the difference was not significant. It is evident from Figure 1 that the increase in bicarbonate output was caused by the increase in both volume and bicarbonate concentration. Compared with control values, the maximal rise in bicarbonate output averaged $50 \%$.

Figure 2 shows the effect of met-enkephalin on protein concentration and output. Met-enkephalin caused a slight but significant increase in protein output. The increase, which reached $22 \%$ of the control values, was exclusively caused by the increase in volume, as protein concentration was not significantly affected by met-enkephalin.

The administration of met-enkephalin caused no symptoms in any of the patients.

\section{Discussion}

The aim of this study was to determine the effect of met-enkephalin on human exocrine pancreatic secretion. In order to avoid possible interferences of bile or other gastrointestinal secretions, as well as of the activity of the sphincter of Oddi, the study was carried out directly on pure pancreatic juice collected by drainage of the main pancreatic duct. Pancreatic secretion was stimulated by secretin and cerulein in doses which mimic the normal postprandial stimulation. ${ }^{4}$ The results showed that, under these conditions, the administration of a very low dose of met-enkephalin causes a prompt and marked rise in bicarbonate output, and a less pronounced increase in enzyme output. The effect of metenkephalin on pancreatic juice flow and bicarbonate secretion seen in this study is similar to the effect of morphine shown in our previous study. 'The results of the two studies, however, do not completely agree as far as the effect of the two opioids on enzyme secretion is concerned. Morphine, in fact, caused an initial, rapid increase in enzyme secretion, followed by a slight and more prolonged decrease. This decrease was caused by a marked reduction in enzyme concentration, which became manifest 10 minutes after the beginning of morphine infusion. In the present study, enzyme concentration was not affected by met-enkephalin. The reason for the discrepancy is not clear. One possible explanation is the involvement of different classes of opiate receptors by morphine and met-enkephalin. Indeed it is known that morphine is addressed preferentially to mu receptors, whereas met-enkephalin has greater affinity for delta receptors. ${ }^{8}$ Another possibility is that morphine may have actions other than stimulation of opiate receptors on pancreatic acinar cells. For example, the drug has been shown to inhibit acetylcholine release from cholinergic nerves," and this anticholinergic action might account for its depressing effect on pancreatic enzyme secretion. Finally, morphine was given at a dose of $40 \mu \mathrm{g} / \mathrm{kg} / \mathrm{h}$, which is considerably greater than that of metenkephalin. It is possible that low concentrations of opioids might play a facilitatory role in enzyme secretion, whereas higher doses might inhibit it.

To our knowledge, the effect of enkephalin on human pancreatic secretion had been investigated only in a study by Konturek et $\mathrm{al}^{10}$ who reported that the administration of the enkephalin analogue (ala-enk) inhibited pancreatic secretion induced by secretin or vagal stimulation. Several methodological differences between Konturek's and our own study may explain the different results obtained. First, Konturek et $a l^{10}$ evaluated the effect of a met-enkephalin analogue not on the pure pancreatic juice, but on the duodenal contents. The significance of their results is open to question because opioids are known to both inhibit biliary secretion, 

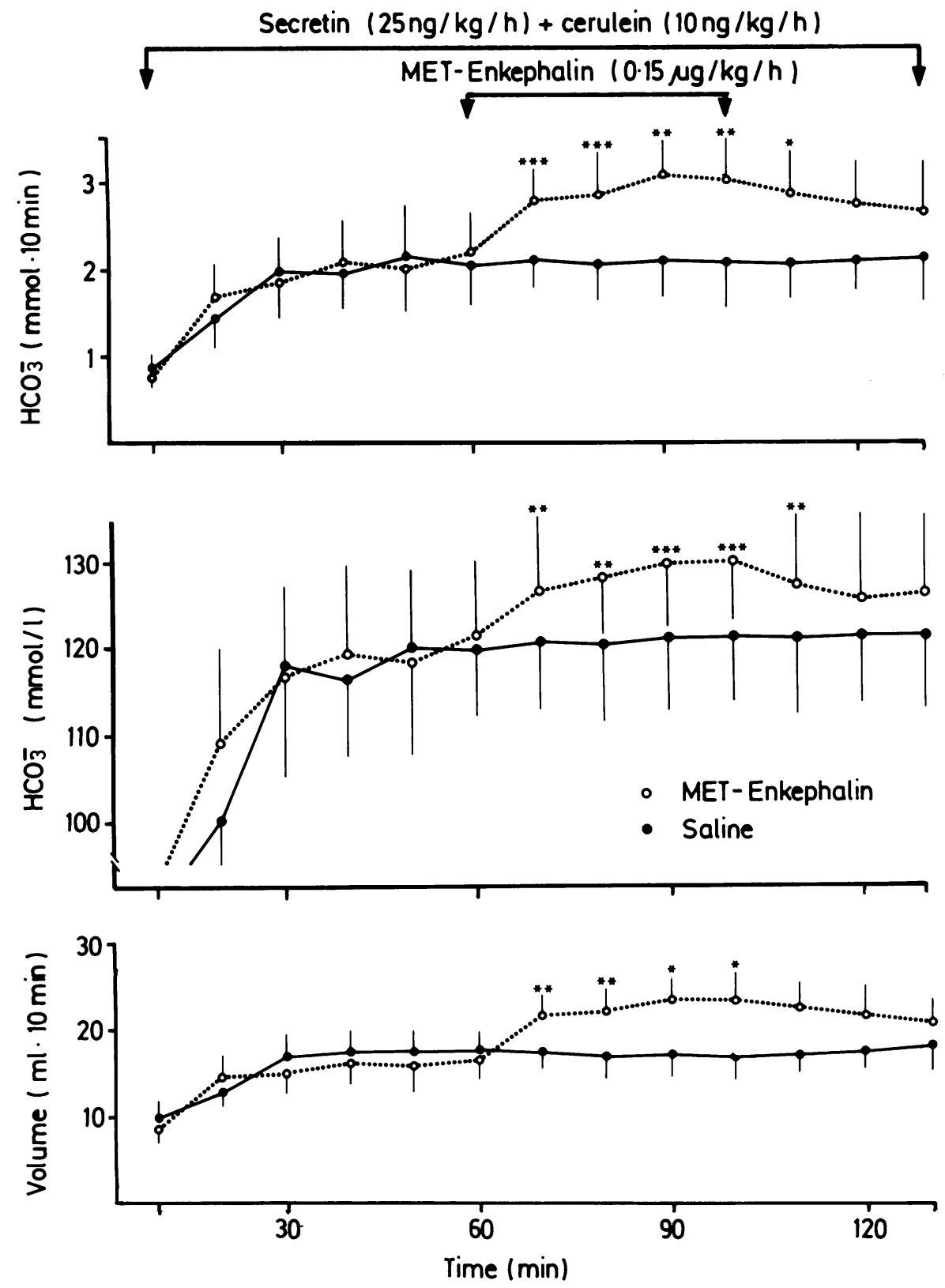

Fig. 1 Effect of met-enkephalin on pancreatic juice flow and bicarbonate concentration and output. Means $\pm S E M$. ${ }^{*} p<0 \cdot 05,{ }^{* *} p<0 \cdot 02,{ }^{* * *} p<0 \cdot 005$, when compared with control experiments.

and contract the sphincter of Oddi. ${ }^{12} 13$ Thus, these drugs can greatly reduce the secretory outputs into the duodenum simply as a consequence of these other actions. Second, a large, pharmacological dose of enkephalin was used in the Konturek's study, whereas we used a low dose. Third, in their study the effect of enkephalin was assessed during pancreatic stimulation with a maximal dose of secretin, whereas we used a much lower secretin dose.

Met-enkephalin has been reported to inhibit pancreatic secretion in some experimental 


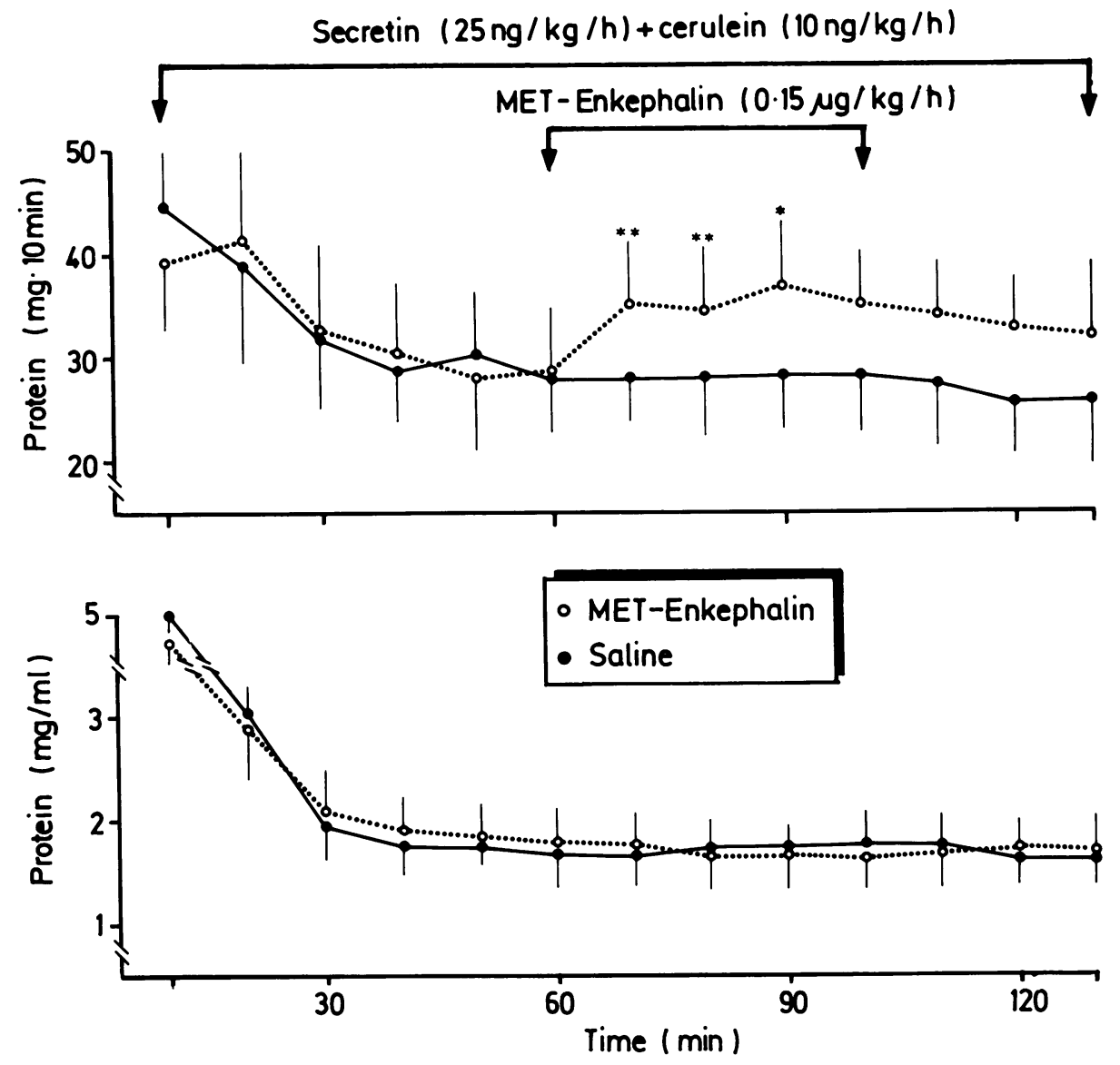

Fig. 2 Effect of met-enkephalin on pancreatic proteinconcentration and output. Means $\pm S E M .{ }^{*} p<0 \cdot 01,{ }^{* *} p<0 \cdot 005$, when compared with controlstudies.

animals. ${ }^{14}$ is Species as well as methodological differences may well explain the discrepancy with the results in man.

Met-enkephalin is widely distributed in the gastrointestinal tract, ${ }^{16}$ but its physiological role is still unknown. In previous studies we ${ }^{17}$ and others ${ }^{18}$ have shown that sham feeding produces a rise not only in pancreatic enzyme secretion, but also in water and bicarbonate secretion. These observations taken in conjunction with evidence for non-cholinergic fibres in the vagus which stimulate pancreatic bicarbonate secretion ${ }^{99}$ and the distribution of met-enkephalin in the pancreas ${ }^{16}$ and vagus, ${ }^{19}$ suggest the possibility that met-enkephalin might be involved in a noncholinergic mechanism which stimulates water and electrolyte secretion during the cephalic phase of pancreatic secretion. This hypothesis is further supported by the present work which shows that met-enkephalin is able to stimulate bicarbonate output by the pancreas.

Recent studies have shown that met-enkephalin circulates in the human plasma, and that a significant portion of the circulating peptide may originate from sources other than the adrenal gland, including the gastrointestinal tract. ${ }^{20-22}$ The functional role of plasma enkephalin is uncertain and whether it has any physiological importance for pancreatic secretion remains to be elucidated.

\section{References}

1 Gullo L, Priori P, Costa PL, et al. Effects of morphine on human pancreatic secretion: studies on pure pancreatic juice. Gut 1982; 23: 739-43.

2 Gullo L, Priori P, Costa PL, Mattioli G, Labò G. Action of secretin on pancreatic enzyme secretion in 
man. Studies on pure pancreatic juice. Gut 1984; 25: 867-73.

3 Tournut R, White TT. Water, electrolyte, and protein secretions of the human exocrine pancreas in the early postoperative period. Surg Gynecol Obstet 1972; 135: 17-21.

4 Greenberg GR, Adrian TE, Baron JH, McCloy RF, Chadwick VS, Bloom SR. Inhibition of pancreas and gallbladder by pancreatic polypeptide. Lancet 1978; ii: $1280-2$.

5 Skov Olsen P, Kirkegaard P, Petersen B, Lendorf A. Christiansen J. The effect of a synthetic metenkephalin analogue (FK 33-824) on gastric acid secretion and serum gastrin in man. Scand J Gastroenterol 1981; 16: 531-3.

6 Van Slyke DD, Neil JM. The determination of gases in blood and other solutions by vacuum extracting and manometric measurement. J Biol Chem 1924; 61: 523-73.

7 Figarella C, Ribeiro T. The assay of human pancreatic phospholipase $\mathrm{A}$ in pancreatic juice and duodenal contents. Scand J Gastroenterol 1971; 6: 133-7.

8 Lord JAH, Waterfield AA, Hughes J, et al. Endogenous opioid peptides: multiple agonists and receptors. Nature 1977: 267: 495-9.

9 Paton WDM. The action of morphine and related substances on contraction and on acetylcholine output of coaxially stimulated guinea-pig ilcum. Br J Pharmacol 1957; 12: 118-28.

10 Konturek SJ, Kwiecien N, Dobrzanska M, Gawronek J, Oleksy J, Coy DH. Effect of enkephalin and naloxone on vagal and hormonal stimulation of pancreatic secretion in man. Scand J Gastroenterol 1983. 18: 679-84.

11 Bowman WC, Rand MJ. Textbook of pharmacology. Oxford: Blackwell, 1980
12 Salik JO, Siegel CI, Mendeloff AI. Biliary-duodenal dynamics in man. Radiology 1973; 106: 1-11.

13 Worobetz LJ, Baker RJ, McCallum JA, Wells G, Sullivan SN. The effect of naloxone, morphine, and an enkephalin analogue on cholecystokinin octapeptidestimulated gallbladder emptying. Am J Gastroenterol 1982: 77: 509-11.

14 Konturek SJ, Tasler J, Cieszkowski M, Jaworek J, Coy DH. Schally AV. Inhibition of pancreatic secretion by enkephalin and morphine in dogs. Gastroenterology 1978: 74: 851-5.

15 Rozé C, Dubrasquet M. Chariot J, Vaille C. Central inhibition of basal pancreatic and gastric secretions by $\beta$-endorphin in rats. Gastroenterology 1980; 79: 659-64.

16 Polak JM, Bloom SR, Sullivan SN, Facer P. Pearse AGE. Enkephalin-like immunoreactivity in the human gastrointestinal tract. Lancet 1977; 1: 972-4.

17 Fontana G, Gullo L, Tessari R. Ricerche sulla fase cefalica della secrezione pancreatica ottenuta mediante intubazione del Wirsung nelluomo. Giorn Clin Med 1971: 52: 855-74.

18 Sarles H, Dani R, Prezelin G, Souville C, Figarella C. Cephalic phase of pancreatic secretion in man. Gut 1968; 9: 214-21.

19 Lundberg JM. Hokfelt T. Kewenter J, et al. Substance $P$. VIP, and enkephalin-like immunoreactivity in the human vagus nerve. Gastroenterology 1979; 77: 468-71.

20 Clement-Jones V, Lowry PJ, Rees LH, Besser GM. Met-enkephalin circulates in human plasma. Nature 1980; 283: 295-7.

21 Ryder SW, Eng J. Radioimmunoassay of leucineenkephalin-like substance in human and canine plasma. $J$ Clin Endocrinol Metab 1981; 52: 367-9.

22 Simth R, Grossman A, Gaillard R, et al. Studies on circulating met-enkephalin and $\beta$-endorphin: normal subjects and patients with renal and adrenal disease. Clin Endocrinol 1981; 15: 291-5. 